Perkembangan Anak Disabilitas... Oleh: Siti Wahyuni

\title{
PERKEMBANGAN ANAK DISABILITAS \\ (ANAK TUNARUNGU BELAJAR MELALUI METODE ORAL)
}

\author{
Oleh: \\ Siti Wahyuni \\ yunilirboyo@gmail.com \\ Institut Agama Islam Tribakti (IAIT) Kediri
}

\begin{abstract}
Oral method is one way to train deaf children to be able to communicate orally (verbally) with neighborhood who heard that deaf children are required to speak demanded their participation of the people around them, involving deaf children to speak orally in every in every chance. By giving a chance to talk to them, get it implies that deaf children are motivated to get used to speak verbally deaf children get difficulties in developing spoken language because of lack or do not hear the sounds of the language, because of hearing function is not maximized, whereas deaf children generally still have residual hearing. To overcome these difficulties oral method suitable to be used.
\end{abstract}

Keywords: Disability, Hearing Disorders, Oral Method.

\section{Pendahuluan}

Anak merupakan salah satu anugerah terindah dari Allah bagi semua orang tua. Tidak dapat dinafikan, kehidupan rumah tangga pasti menjadi lebih ceria dan menyenangkan dengan kehadiran anak-anak. Namun begitu, orang tua harus menyadari bahwa anugerah ini juga datang dengan sebuah tanggungjawab yang besar, yaitu tanggung jawab untuk mendidik dan membentuk anak agar menjadi seorang insan yang berguna dan cemerlang. Apabila orangtua diberi titipan anak penyandang 
Perkembangan Anak Disabilitas... Oleh: Siti Wahyuni

disabilitas, maka orangtua harus bisa memahami anak. Karena hal itu merupakan salah satu tanggung jawab orangtua.

Anak tunarungu adalah anak yang mengalami kekurangan dalam kemampuan mendengar. Namun demikian, indera visual dan indera lainnya masih berfungsi dan dapat digunakan secara optimal untuk membantu mereka berkomunikasi. Artinya, perkembangan akademiknya yang lamban disebabkan oleh keterbatasan bahasa dan wicara sebagai dampak dari hambatan dalam berkomunikasi karena kemampuan bicara dan bahasa merupakan alat utama bagi manusia dalam berkomunikasi. ${ }^{1}$

Pada masa modern ini, anak tunarungu atau yang mengalami hambatan belajar lain baik secara fisik, mental dan emosional dapat melanjutkan pendidikannya di sekolah formal dari jenjang pendidikan dasar hingga pendidikan tinggi. Inilah yang disebut sebagai pendidikan inklusi. Berkat program inklusi dalam pendidikan, banyak lulusan dari mereka yang dikategorikan sebagai orang yang berkebutuhan khusus atau penyandang disabilitas menjadi orang sukses. Misalnya, Helen Keller (penyandang cacat ganda). Dia menjadikan hambatan atau keterbatasannya sebagai sarana menuju pencapaian prestasinya sebagai penulis, aktivis politik dan dosen. ${ }^{2}$

Anak kebutuhan khusus berhak mendapatkan pendidikan dan pengajaran yang layak sesuai dengan kemampuan dan juga potensi yang dimiliki setiap anak. Anak berkebutuhan khusus di kategorikan sebagai anak yang mempunyai kelainan dalam hal fisik, mental dan emosional. Anak tunarungu di sini juga termasuk anak berkebutuhan khusus yang juga berhak mendapatkan layanan pendidikan. Mereka juga membutuhkan layanan pendidikan seperti anak pada umumnya. Di mana

1 Abdul Hadis, Pendidikan Anak Berkebutuhan Khusus-Autistik (Bandung: Alfabeta, 2006), h. 17.

2 J. David Smith, Inklusi: Sekolah Ramah untuk Semua terj. Denis dan Enrica (Bandung: Penerbit Nuansa, 2009), h. 32.

Volume 29 Nomor 1 Januari-Juni 2018 
layanan pendidikan yang diberikan harus disesuaikan dengan tingkat kemampuan dan potensi anak.

Anak tunarungu adalah anak yang mengalami gangguan pada salah satu inderanya, yaitu indera pendengaran sehingga mereka mempunyau hambatan dalam melakukan aktifitas sehari-hari, seperti mendengar, berbicara, bersosialisasi dengan lingkungan dan aktifitas belajarnya. Ketunarunguan dapat disebabkan oleh banyak faktor dan bisa terjadi setiap saat. Terjadinya ketunarunguan dapat dibagi menjadi 3 yaitu, pada saat prenatal, natal, dan post natal. Untuk segi intelegensi, anak tunarungu mempunyai intelegensi normal sepeti anak pada umumnya. $^{3}$

Di dalam proses komunikasi diperlukan beberapa metode yang harus dikuasai/oleh guru sebagai pengajar, karena guru yang secara langsung berhadapan dengan siswa. Pemilihan metode yang tepat dapat membantu guru dalam menyampaikan materi dan memudahkan siswa dalam menerima materi yang disampaikan. Dalam aktifitas berbicara, anak tunarungu banyak mengalami hambatan dalam menerima informasi, untuk itu anak tunarungu perlu mendapatkan sistem layanan khusus untuk meningkatkan proses berbicara. Model layanan khusus yang diberikan untuk anak tunarungu tergantung dari tingkat ketunarunguannya. Pada umumnya sekolah khusus untuk anak tunarungu menggunakan media isyarat untuk pembelajarannya.

Hasil penelitian menjelaskan anak berkebutuhan khusus dapat diajar dengan menggunakan metode ceramah, diskusi dan praktek, serta penggunan isyarat yang dilakukan oleh guru bergantung pada kelas yang sedang dihadapi. ${ }^{4}$ Metode oral merupakan salah satu cara yang dapat digunakan untuk melatih

${ }^{3}$ Sutjihati Somantri, Psikologi Anak Luar Biasa (Bandung: PT. Refika Aditama, 2006), h. 5.

${ }^{4}$ M. Maftuhin and A. Jauhar Fuad, "Pembelajaran Pendidikan Agama Islam Pada Anak Berkebutuhan Khusus," Journal An-Nafs: Kajian Penelitian Psikologi 3, no. 1 (June 24, 2018), h. 1. 
anak tunarungu dapat berkomunikasi secara lisan (verbal) dengan lingkungan orang yang mendengar. Agar anak tunarungu mampu berbicara dan berpartisipasi dengan orangorang di sekelilingnya, yaitu dengan melibatkan anak tunarungu bicara secara lisan dalam setiap kesempatan. Diberikannya kesempatan kepadanya bicara maka secara tidak langsung anak termotivasi membiasakan bicara secara lisan.

Menurut Lani Bunawan, suara meraban anak tunarungu tidak terlalu berbeda dengan anak yang mendengar sampai usia 12 bulan. Setelah usia tersebut anak bisa mendengar dan mengucapkan kata-kata, sedangkan bayi yang tunarungu akan menjadi bisu. Konsonan yang biasa diucapkan sewaktu meraban akan hilang satu persatu akhirnya vokal akan hilang juga. ${ }^{5}$

Para ahli menganjurkan adanya deteksi dan bimbingan dini dalam penanganan anak tunarungu. Hal yang terpenting adalah harus ada hubungan yang erat antara pengamatan dengan eksplorasi aktif yang mendasari sebelumnya. Hanya dengan demikian bicara akan menjadi suatu kecakapan yang merupakan bagian integral dalam totalitas kemampuan anak. Untuk keberhasilan hal tersebut, dianjurkan untuk menerapkan prinsip cybernetik (umpan balik, yaitu prinsip yang menekankan perlunya suatu pengontrolan diri). Setiap organ bicara yang menimbulkan bunyi, dirasakan dan diamati sehingga hal itu akan memberi umpan balik terhadap gerakannya yang akan menimbulkan bunyi selanjutnya. Selain itu, bila mungkin anak dibantu dengan memanfaatkan alat bantu dengar sehingga dalam batas tertentu dapat mendengar suaranya sendiri.

Menurut beberapa peneliti diketahui bahwa penggunaan metode oral di sekolah diajarkan hanya satu metode yaitu ceramah dengan guru menjelaskan dan siswa cenderung hanya mendengar tanpa ada variasi seperti pemanfaatan media dan

${ }^{5}$ Lani Bunawan, Komunikasi Total (Jakarta: Departemen Pendidikan dan Kebudayaan, 1997), h. 27. 
sebagainya. Alasan dari kegiatan belajar mengajar yang monoton ini adalah kurangnya peralatan laboratorium dan fasilitas yang lainnya menyebabkan kegiatan seperti pratikum sangat sukar diterapkan.

Maka dari itu mengingat anak tunarungu sulit untuk menerima stimulus yang bersifat auditif dan anak tunarungu berusaha untuk memahami lingkungan melalui indera visualnya, untuk melatih keterampilan berbicara anak tunarungu diperlukan suatu metode yang disesuaikan dengan kondisi anak. Dalam tulisan ini akan diuraikan mengenai pemanfaaatan metode oral bagi anak tunarungu untuk mengetahui apakah penggunaan metode oral pada anak tunarungu terealisasi secara maksimal di Sekolah Dasar Luar Biasa (SDLB)-B Putera Asih Kediri.

\section{Pembahasan}

\section{Metode Oral}

Pengajaran memiliki peranan yang sangat penting dalam menentukan keberhasilan proses dan keberhasilan belajar. ${ }^{6}$ Ada tiga dasar pendekatan pengajaran alternatif bagi siswa dengan gangguan pendengaran, khususnya bagi mereka yang tidak dapat mengembangkan dan atau memakai alat bantu komunikasi standar, yaitu metode manual, metode oral, dan metode komunikasi total. $^{7}$

Ciri pelayanan pendidikan metode oral pada masa kini berdasarkan perumusan pada simposium internasional tentang pendekatan oral di Belanda tahun 1979 adalah, 1) suatu sistem komunikasi yang menggunakan bicara, sisa pendengaran, baca ujaran, dan atau rangsangan vibrasi serta perabaan (vibrotaktil) untuk suatu percakapan spontan, 2) suatu sistem pendidikan di

6 Jauhar Fuad, "Strategi Pembelajaran Kooperatif (Studi Eksperimen)," Jurnal Pemikiran Keislaman 20, no. 1 (March 3, 2013): 1, http://ejournal.iai-tribakti.ac.id/index.php/tribakti/article/view/94.

7 J. David Smith, Inklusi: Sekolah Ramah untuk Semua terj. Denis daan Enrica (Bandung: Penerbit Nuansa, 2009), h. 283. 
Perkembangan Anak Disabilitas... Oleh: Siti Wahyuni

mana kegiatan belajar mengajar berlangsung dengan menggunakan bahasa lisan dan tulisan. Pendekatan seperti ini juga dikenal dengan sebutan AVO (Auditory/Visual/Oral) atau juga oral murni karena sama sekali tidak meggunakan bahasa isyarat selain isyarat lazim (gesture) atau ungkapan badani sebagaimana digunakan manusia dalam berkomunikasi pada umumnya. $^{8}$

Menurut Smith, pendekatan oral menekankan pada pembimbingan ucapan dan membaca ucapan (speechreading). Metode oral difokuskan pada pemanfaatan pendengaran yang tersisa (residual hearing) yang mungkin masih dimiliki siswa melalui pertolongan alat bantu dengar dan pelatihan khusus. Penekanannya pada meningkatkan sensitifitas terhadap suara dan kemampuan dalam membedakan suara yang berbeda. Siswa juga dilatih cara menggunakan dan memonitor bunyi suara dalam ucapan.

Sedangkan membaca ucapan (speechreading, biasa disebut lipreading) menggunakan isyarat-isyarat visual untuk membantu memahami ucapan orang lain. Dalam hal ini, siswa dilatih memperhatikan gerak bibir, posisi bibir, serta gigi agar dapat memahami apa yang sedang diucapkan. Selain itu, mereka juga diajarkan membaca isyarat seperti ekpresi wajah untuk memudahkan pemahaman mereka atas apa yang diucapkan. ${ }^{9}$

\section{Konsep Dasar Berbicara dan Tunarungu}

Kirk menjelaskan bahwa berbicara merupakan suatu aktifitas fisik individual dengan kemampuan untuk mengucapkan perpaduan bunyi-bunyi berupa kata-kata,

8 Edja Sadjaah, Pendidikan Bahasa Bagi Anak Gangguan Pendengaran dalam Keluarga (Jakarta: Depdiknas, 2005), h. 68.

${ }^{9}$ Smith, Inklusi, h. 285-286. 
kemudian kata-kata tersebut menjadi suatu yang mempunyai arti penuh atau kalimat. ${ }^{10}$

Berdasarkan penjelasan tersebut dapat disimpulkan bahwa berbicara adalah suatu proses yang dilakukan manusia dengan mengucapkan bunyi-bunyi bahasa untuk mengekspresikan atau menyampaikan pikiran, perasaan dengan memanfaatkan nafas, alat-alat ucap, dan syaraf secara terintegrasi. Secara operasional, definisi kemampuan bicara adalah suatu kesanggupan manusia dalam mengucapkan bunyi-bunyi bahasa untuk mengekspresikan atau menyampaikan pikiran, perasaan melalui organ bicara.

Sedangkan tunarungu berasal dari kata tuna yang berarti kurang dan rungu yang berarti pendengaran. Orang atau anak dikatakan tunarungu apabila ia tidak mampu mendengar atau kurang mampu mendengar suara. Anak tunarungu adalah anak yang memiliki kekurangan atau kehilangan kemampuan mendengar yang disebabkan oleh kerusakan atau tidak berfungsinya sebagian atau seluruh alat pendengaran sehingga anak mengalami hambatan dalam perkembangan bahasanya.

Berbagai batasan telah dikemukakan oleh para ahli tentang pengertian tunarungu atau dalam bahasa asing sering disebut sebagai hearing impartment yang meliputi the deaf (tuli) dan hard of hearing (kurang dengar). Jadi, anak tunarungu adalah anak yang mengalami hambatan atau kehilangan kemampuan mendengar, baik sebagian atau keseluruhan yang diakibatkan oleh tidak berfungsinya sebagian atau seluruh alat pendengaran. Hal ini menyebabkan anak tunarungu tidak dapat menggunakan alat pendengarannya secara maksimal dalam kehidupan seharihari sehinga berdampak terhadap kehidupannya secara kompleks. Secara potensial pada umumnya anak tunarungu

10 A. Samuel Kirk \& J. James Gallagen, Educating Exceptional Children (Boston Muffin Company, 1998), h. 129. 
memiliki kemampuan yang relatif tidak berbeda dengan mereka yang tergolong mendengar.

Anak tunarungu berusaha memahami segala sesuatu melalui penglihatan, yaitu mengalihkan pengamatannya pada mata, oleh karena itu anak tunarungu disebut anak visual. Melalui mata, anak tunarungu berusaha memahami bahasa lisan atau oral, selain melihat gerakan (gesture) dan ekspresi wajah lawan bicaranya, mata anak tunarungu juga digunakan untuk membaca gerak bibir seseorang yang berbicara. ${ }^{11}$

Gangguan pendengaran yang dialami anak atau orang tunarungu disebabkan oleh dua penyebab, yaitu penyebab genetic dan penyebab dari lingkungan atau pengalaman (environmental/experiental). Kedua faktor ini mempunyai efek pada pendengaran selama masa pra kelahiran, selama periode kelahiran, dan setelah kelahiran.

Secara genetik, gangguan pendengaran dapat diturunkan orang tua kepada anak-anaknya, baik itu melalui gen-gen resesif maupun gen-gen dominan. Sedangkan faktor lingkungan atau pengalaman terbagi ke dalam beberapa faktor, antara lain: pertama, lahir prematur. Bayi yang lahir secara prematur beresiko tinggi mengalami gangguan pendengaran, prematur juga merupakan faktor terjadinya hambatan lain. ${ }^{12}$

Kedua, campak (viral infection). Rubella merupakan virus yang sering kali dikaitkan dengan kehilangan pendengaran (hearing loss). Kesadaran para wanita hamil dan kemudahan akses vaksin atas virus ini, jumlah penderita gangguan pendengaran yang diakibatkan menjadi lebih sedikit. Virus lain yang dapat menyebabkan gangguan pendengaran adalah radang selaput otak, sumsum tulang belakang, radang otak, gondok, dan influenza.

11 Hermawati dan Somad, Ortopedagogik Anak Tuna Rungu (Bandung: Departemen Pendidikan dan Kebudayaan, 1995), h. 38.

${ }^{12}$ Smith, Inklusi, h. 278. 
Ketiga, Ketidaksesuaian Rh darah (blood incompatibility). Bila seorang wanita denga $\mathrm{Rh}$ darah negatif mengandung janin dengan $\mathrm{Rh}$ darah positif. Ini bisa dicegah melalui obat berdasarkan resep dokter yang disebut Rho Gam. Keempat, radang telinga tengah, yaitu pembentukan cairan di telinga bagian tengah dapat terjadi jika jika saluran eustacheus terhalang disebabkan infeksi atau faktor lain. Kelima, pemakaian obat-obatan terutama yang termasuk dalam kelompok mycin (strapto mycin, neomycin, dan lain-lain). ${ }^{13}$

Boothroyd dalam Abdul Hadis menjelaskan bahwa karakteristik anak yang mengalami kehilangan pendengaran dicirikan oleh masalah sensorik. Masalah sensorik yang dialami anak ditandai dengan gangguan, antara lain: perceptual, bicara, komunikasi, kognitif, sosial, emosional, pendidikan, intelektual dna vokasional. Karakteristik tersebut mesti dipahami oleh orang tua, guru, dan masyarakat untuk mempermudah proses pembelajaran anak di sekolah, di rumah, dan di masyarakat. ${ }^{14}$

Anak tunarungu membutuhkan alat bantu dengar untuk membantu mereka berkomunikasi. Dalam konteks ini penting bagi guru untuk mengetahui apa itu alat bantu dengar dan bagaimana cara kerja dan perawatannya. Pada dasarnya alat bantu dengar adalah miniatur dari sistem alat pengeras suara yang terdiri dari susunan mikrofon untuk mengambil suara, amplifier untuk memperkeras volume suara, dan receiver untuk mengirimkan suara ke telinga. Sumber tenaga sistem ini adalah baterai. Alat bantu dengar pertama, seperti ear trumpets. Saat ini telah banyak bentuk alat bantu dengar, namun semuanya berbasis elektronik. Ada pula yang menggunakan model impan, acochlear implant. Apapun alat bantu dengan yang digunakan

${ }^{13}$ Smith, Inklusi, 279-280.

${ }^{14}$ Hadis, Pendidikan Anak Berkebutuhan Khusus, h. 21. 
Perkembangan Anak Disabilitas... Oleh: Siti Wahyuni

harus dikonsultasikan terlebih dahulu kepada ahlinya, yaitu seorang ahli audiologi agar pemilihan dan perawatannya tepat. ${ }^{15}$

\section{Penggunaan Metode Oral Pada Kemampuan Berbicara Anak Tunarungu}

1. Penggunaan metode oral pada anak tunarungu

Ciri-ciri pelayanan metode oral pada masa kini berdasarkan perumusan simposium internasional tentanf pendekatan oral di Belanda, 1979 yaitu suatu sistem yang menggunakan bicara, sisa pendengaran, baca ujaran, vibrasi serta perabaan untuk suatu percakapan yang spontan. Kegiatan belajar mengajar berlangsung dengan menggunakan bahasa lisan dan tulisan. Pendekatan oral grafik (graphicoral) yaitu menggunakan tulis sebagai sarana guna mengembangkan kemampuan komunikasi oral. Hal ini mengingat anak tunarungu lebih banyak memanfaatkan indera visualnya untuk memahami sesuatu. ${ }^{16}$

2. Pendekatan Auditori Oral

Pendekatan auditory oral didasarkan atas premis mendasar bahwa memperoleh kompetensi dalam bahasa lisan, baik secara reseptif maupun ekspresif, merupakan tujuan realistis bagi anak tunarungu. Kemampuan ini akan berkembang dengan sebaik-baiknya dalam lingkungan di mana bahasa lisan dipergunakan secara ekslusif. Mengajari anak menggunakan sisa pendengaran (residual hearing) yang masih dimilikinya untuk mengembangkan perolehan bahasa lisan merupakan hal yang mendasar dalam pendekatan auditori oral.

Tujuan pengembangan keterampilan mendengarkan adalah mengembangkan kompetensi bahasa lisan, maka

${ }^{15}$ Smith, Inklusi, h. 280-281.

${ }^{16}$ Lani Bunawan, Komunikasi Total (Jakarta: Departemen Pendidikan dan Kebudayaan, 1997), h. 49.

Volume 29 Nomor 1 Januari-Juni 2018 
bunyi ujaran (speech sounds) merupakan stimulus utama yang dipergunakan dalam kegiatan latihan mendengarkan keuntungan utama pendekatan auditori oral ini adalah bahwa anak mampu berkomunikasi secara langsung dengan berbagai macam individu, yang gilirannya dapat memberi anak berbagai kemungkinan pendidikan, pekerjaan, dan kehidupan sosial. Keunggulan berbicara dibanding bahasa isyarat anak tunarungu adalah bahasa bicara lebih fleksibel baik bagi pembicara maupun lawan bicara lebih bebas bila seorang berbicara maka pesan atau ungkapan seolah-olah keluar dari orang lain itu agar sampai pada lawan bicaranya.

Berdasarkan kenyataan di lapangan yaitu di Sekolah Dasar Luar Biasa (SDLB)-B Putera Asih Kediri bahwa pada pelaksanaan metode oral pada anak tunarungu masih rendah karena masih menggunakan bahasa isyarat dan masih banyak guru yang mengalami kesulitan untuk membiasakan anak untuk berbicara secara oral. Begitu juga halnya dengan kegiatan di dalam kelas, ditemukan bahwa masih diterapkannya bentuk pembelajaran konvensional yaitu guru lebih banyak menjelaskan materi tanpa interaksi dan komunikasi dengan siswa menyebabkan tidak meratanya materi yang diberikan oleh guru.

\section{Penutup}

Metode oral merupakan salah satu cara untuk melatih anak tunarungu dapat berkomunikasi secara lisan (verbal) dengan lingkungan orang yang mendengar. Dibutuhkan perencanaan metode oral pada anak tunarungu di SDLB-B putra asih Kediri secara matang sehingga metode oral berjalan sesuai rencana.

Dalam pelaksanaan metode oral pada anak tunarungu di SDLB-B Putra Asih Kediri belum terlalu diterapkan pada proses pembelajaran. Dalam pelaksanaan metode oral siswa tunarungu berjalan kurang maksimal, disebabkan oleh keadaan siswa 
Perkembangan Anak Disabilitas... Oleh: Siti Wahyuni

dalam pelaksanaan metode oral yang heterogen yang mana beragamnya kemampuan intelegensi dan kemampuan motorik siswa serta kurangnya jam pembelajaran serta tidak adanya pembelajaran individual.

Dalam pelaksanaan metode oral hendaknya guru dapat mengelompokkan peserta didik, karena kemampuan peserta didik berbeda-beda bertujuan untuk membantu keberhasilan dari program pembelajaran. 
Bunawan, Lani. Komunikasi Total. Jakarta: Departemen Pendidikan dan Kebudayaan, 1997.

Fuad, Jauhar, "Strategi Pembelajaran Kooperatif (Studi Eksperimen)," Jurnal Pemikiran Keislaman 20, no. 1 (March 3, 2013): 1, http://ejournal.iaitribakti.ac.id/index.php/tribakti/article/view/94

Hadis, Abdul. Pendidikan Anak Berkebutuhan Khusus-Autistik. Bandung: Alfabeta, 2006.

Maftuhin M. and A. Jauhar Fuad, "Pembelajaran Pendidikan Agama Islam Pada Anak Berkebutuhan Khusus," Journal An-Nafs: Kajian Penelitian

Hermawati dan Somad. Ortopedagogik Anak Tunarungu. Bandung: Departemen Pendidikan dan Kebudayaan, 1995.

Kirk, A. Samuel \& J. James Gallagen. Educating Exceptional Children. Boston: Muffin Company, 1998.

Sadjaah, Edja. Pendidikan Bahasa Bagi Anak Gangguan Pendengaran dalam Keluarga. Jakarta: Depdiknas, 2005.

Smith, J. David. Inklusi: Sekolah Ramah untuk Semua terj. Denis dan Enrica. Bandung: Penerbit Nuansa, 2009.

Somantri, Sutjihati. Psikologi Anak Luar Biasa. Bandung: PT. Refika Aditama, 2006. 